\title{
Digitalization of Industry as a Key Factor in the Competitiveness of the Socio-economic System*
}

\author{
Sergey Tolkachev \\ Financial University under Government of the Russian Federation \\ Moscow, Russia \\ E-mail: SATolkachev@fa.ru
}

\author{
Antonina Sharkova \\ Financial University under Government of the Russian \\ Federation \\ Moscow, Russia \\ E-mail: ASharkova@fa.ru
}

\author{
Dmitry Morkovkin \\ Financial University under Government of the Russian \\ Federation \\ Moscow, Russia \\ E-mail: MorkovkinDE@mail.ru
}

\begin{abstract}
The paper analyzes the impact of digital business on the formation of competitive advantages in the socioeconomic system in the Russian economy. The article substantiates the position that the government of the Russian Federation could significantly support the digitalization of the Russian economy and improve the competitiveness of its socioeconomic system by developing a long-term strategy for the modernization of the country's industry on the basis of the principles of "Industry 4.0".
\end{abstract}

Keywords - digital economy; socio-economic system; industry; competitiveness; digital business; industry 4.0; digitalization of industry; innovation; digital technology; industrial policy

\section{INTRODUCTION}

In modern conditions of development of world economic relations and increasing global competition of national socioeconomic systems, a significant effect of the introduction of digital technologies at the macroeconomic level can be obtained in the manufacturing industry due to its high complexity and technological lag of Russia from advanced countries. Here, a major breakthrough in the field of efficiency growth is possible in all parts of the value chain - from the intensification of the development and market launch of new products, synchronization of the production chain and the supply of components to a significant increase in efficiency at each stage of the reproduction process from planning, production, quality control to the level of service Thanks to the modernization of the Russian engineering industry based on the principles of "Industry 4.0" can significantly improve productivity in this industry, reducing the gap from the most industrialized countries.

According to some scientists, the digital economy is a system of socio - economic, cultural, organizational and

*The article is executed in the framework of research "Development of the model of competitiveness of socio-economic systems in the digital economy" on the state task at 2018 of the Financial University under Government of the Russian Federation. technical relations, which are based on the use of digital information and telecommunication technologies [1]. The concept of the digital economy was normatively enshrined in the Strategy of development of the information society in the Russian Federation for 2017-2030, which defined the digital economy as an economic activity, the most important factor in which is digital data, processing and use of large volumes of which will significantly improve the efficiency of various types of production, storage, sale and delivery of goods and services compared to traditional forms of management in order to increase the level of socio-economic development of the state [2]

The Russian economy as a whole is still significantly behind the level of digitalization from the developed countries of the world. According to McKinsey, the share of the digital economy in Russia barely reaches $4 \%$, while in the US: 11, China: 10, EU: 8 countries, the Czech Republic, Brazil: 6, India: 5.5 [3].

According to the level of digitalization, the most important industries for Russia - mining, manufacturing and transport lag behind the EU countries most. International experience shows that it is difficult for industries lagging behind in terms of digitalization to overcome the gap with the leading industries [4]. This is due to the fact that companies with low digital culture are unattractive for the relevant specialists. In addition, lagging companies do not have the skills and resources to develop, implement and scale up new digital tools, products and services, which reduces their competitiveness [5].

\section{TRAJECTORIES OF DigitAl DEVELOPMENT OF THE INDUSTRIAL SECTOR OF THE ECONOMY}

The current policy of Informatization of the industrial sector is to create a unified state information system of industry (GIS) on the basis of the Ministry of industry and trade of Russia. Within the framework of this service, a single cross-sectoral Russian platform b2b was created, 
through which the interaction of participants in the production cycle is carried out: enterprises; development institutions and investors; industry associations, unions, certified centers; public authorities [6], [7]. At the end of 2017, the turnover of the electronic trading platform GISP amounted to 1140000 million rubles. In addition to the trade service, GISP provides financial services, technology and personnel transfer services, interaction with public authorities, information services.

In the process of digitalization of the national economy plays an important role the state, which provides legal support and financing of these projects. Thus, according to the Decree of the government of the Russian Federation "on the implementation of the National technology initiative" dated April 18, 2016 No.317 developed an action plan road map "TechNet", which clearly defines the targets for the development of digital and intellectual production. If the Roadmap is implemented, by 2035 Russia will be able to enter the ranking of the top 10 countries in the world that have implemented advanced production technologies in their industrial sector in "Table I".

The assessment of the target indicators of the road map of digitalization of the Russian industry shows that Russia sets quite achievable goals for entering the world market of
IT — technologies and implementation of its own information restructuring of the production complex. It is also worth emphasizing that the digitalization of the Russian industry is a strategic direction of the state, which is an integrator of the ongoing processes, while controlling the entire course of the transition to the online platform. In this process, the state will play the role of an integrator, initiate the creation of digitalization infrastructure and ensure the availability of the system for potential participants, and companies will develop the digital industry themselves [8].

It should be remembered that situations should take into account all the risks and threats accompanying the restructuring of economic entities. The main risks are the attacks of cybercriminals, as the results of 2016 alone showed a significant increase in attacks and hacking of information systems of various enterprises and organizations. In this regard, there is a need to assess the existing risks and challenges associated with the expansion of the range and scope of digital services, including in industry.

Summing up the assessment of the dynamics of the industrial sector growth, we note that the industry is transforming and moving from production to processing, which is an indicator of a new qualitative level of production [10].

TABLE I. THE TARGETS OF THE ROAD MAP - TECHNET" [9]

\begin{tabular}{|c|c|c|c|c|c|c|c|}
\hline Indicator & Measure unit & Current value & 2017 & 2018 & 2019 & 2025 & 2035 \\
\hline $\begin{array}{l}\text { Russia's share in the world markets of "Factories of the } \\
\text { future" in the segment of engineering and design }\end{array}$ & $\%$ & $0,28 \%$ & $0,3 \%$ & $0,4 \%$ & $0,5 \%$ & $0,9 \%$ & $1,5 \%$ \\
\hline $\begin{array}{l}\text { Number of companies-service providers for the creation } \\
\text { Of factories of the future in the ranking of the top } 50 \\
\text { technological gazelles of the Russian Federation }\end{array}$ & units' & 0 & 0 & 1 & 3 & 10 & 20 \\
\hline $\begin{array}{l}\text { Russia's position in the Global Manufacturing } \\
\text { Competitiveness Index (or comparable) }\end{array}$ & place & 32 & 33 & 30 & 28 & 20 & 10 \\
\hline $\begin{array}{l}\text { The export volume of the products obtained with the use } \\
\text { of PPT }\end{array}$ & $\begin{array}{l}\text { thousand } \\
\text { rubles }\end{array}$ & - & - & - & 1500000 & 80000000 & 800000000 \\
\hline $\begin{array}{l}\text { The number of created Factories of the Future } \\
\text { "TechNet» }\end{array}$ & units' & 0 & 0 & 3 & 5 & 17 & 40 \\
\hline $\begin{array}{l}\text { Number of test sites to be created (Testbed) "Factories of } \\
\text { the future» }\end{array}$ & units' & 0 & 2 & 3 & 4 & 10 & 25 \\
\hline $\begin{array}{l}\text { Number of experimental digital centers (laboratories) of } \\
\text { Russian Federation certification }\end{array}$ & units' & 0 & 0 & 1 & 3 & 10 & 15 \\
\hline $\begin{array}{l}\text { Number of specialists trained and retrained in advanced } \\
\text { production technologies }\end{array}$ & $\operatorname{man}$ & Not less than 30 & $>200$ & 1000 & 2000 & 20000 & 50000 \\
\hline
\end{tabular}

\section{ANALYSIS OF THE IMPACT OF DIGITAL BUSINESS ON FORMATION OF COMPETITIVE ADVANTAGES OF SOCIO- ECONOMIC SYSTEMS IN THE RUSSIAN ECONOMY}

Digitalization opens up interesting prospects for business to improve efficiency in the field of inventory management and logistics processes of the enterprise. The introduction of automated supply chain management systems allows achieving significant optimization of stocks of finished products, raw materials, spare parts stored in the warehouses of the enterprise. Digital tools also reduce logistics costs, help to plan routes more effectively, control the load of transport, and more accurately prioritize logistics operations throughout the enterprise.
"Industry 4.0" technologies make a significant contribution to the improvement of production safety and labor protection at enterprises. First of all, it concerns the possibility of placing sensors on equipment and personnel for automated monitoring of their movements on the production site, analysis of potentially dangerous actions, prevention of injuries and accidents at work.

The process of developing new product types can also be improved with the help of Industry 4.0 tools. Based on the analysis of data on the actual use of products by customers, the development of new types of products, as well as improving the efficiency of the pre-sale analysis process when introducing new products to the market can be carried out. 
The introduction of individual elements of modern it systems can also lead to improvements in staff productivity. Modern systems with access to data from production lines allow to reduce the number of mistakes made by employees due to the optimal supply of raw materials, to ensure a more complete load of production equipment and to reduce the amount of waste.

The primary task of digital business is to identify promising areas of application of "Industry 4.0" technologies, as well as the development and implementation of a strategy for their development. To successfully implement such a strategy, it is necessary to clearly explain the benefits of digital technologies at all levels of management, to create a digital culture within the company that encourages experimentation and rapid development of new technologies.

The presence of digital specialists in the company is the most important factor in the success of the digital strategy, so it is necessary to create a system of selection and retention of such personnel and training of existing and potential employees in digital disciplines. For this purpose, it is necessary to develop educational programs in cooperation with technology companies, universities and vocational education organizations, including the provision of dual specialties and training in enterprises.

The development of "Industry 4.0" technologies requires a concentration of resources, so companies need to form industry partnerships for joint financing of projects, risk reduction, interaction with government agencies, technology companies and research centers, within which to create expert consulting centers, model enterprises, to develop industry platforms, solutions and standards.

Large companies can interact with technology entrepreneurs and digital specialists by creating their own venture funds and business incubators specializing in Industry 4.0 technologies, as well as through technology competitions aimed at solving specific problems and business problems.

Russia already has the necessary technological groundwork to offer the domestic market high-quality solutions in the field of "Industry 4.0"technologies. On the basis of the innovation center "SKOLKOVO" created by the cluster of information technologies, where the focus of the company, leading the development and already have the finished products in all segments of Industry 4.0; formed two national consortium of Internet of things - the Russian Association of Internet of things on the basis of "SKOLKOVO" and the national consortium of industrial of the Internet, created by "Rostelecom". The company also stated its desire to work in the industrial Internet market and create its own platform Mail.ru ahhh! At the enterprises of machine-tool and aerospace industries, an integrated platform for the industrial Internet of things of Russian production relating to the technologies of "Industry 4.0"has already been introduced. Moreover, the Russian software solution in the field of computer-aided design is used by Airbus, and unmanned systems for forklifts of the Russian innovative company are used in the warehouses of Volkswagen and Samsung.
The development by the Russian Government of a longterm strategy for the modernization of the country's industry on the basis of the principles of "Industry 4.0" and the use of financial and non-financial mechanisms to stimulate demand from companies for such technologies could significantly support the digitalization of the Russian economy and improve the competitiveness of its socio-economic system. At the same time, it is important to motivate the industrial business to attract Russian suppliers, engineering companies and research centers for the development and implementation of these technologies. Through this approach, domestic demand will drive the development of local technology companies and platforms. As part of this strategy, the government could develop programs to localize advanced foreign developments [4], increase government funding for $\mathrm{R} \& \mathrm{~d}$ in the field of digital industrial technologies, subsidize the creation of experimental sites for testing Russian technologies.

An important element of the state policy will be the training of personnel in the field of new industrial technologies, as well as support for corporate and regional programs of retraining and advanced training, digital literacy and development of new technologies by the personnel of Russian industrial enterprises [11].

The state program "the Digital economy of the Russian Federation" approved by the Decree of the Government dated 28 July, 2017 No. 1632-p, defines the goals and objectives within the framework of 5 basic directions of development of digital economy in the Russian Federation for the period up to 2024, which are defined in more detail in the framework of the national development objectives of presidential Decree No. 204 of 08.05.2018 [12].

The basic directions include regulatory regulation, personnel and education, the formation of research competencies and technical reserves, information infrastructure and information security [13].

In our opinion, the issues of industrial modernization within the framework of this Program are planned in insufficient volume and format.

In the direction of the formation of the digital economy ecosystem, which is closely related to the industry, it is planned to achieve the following indicators by 2024 :

"successful operation of at least 10 leading companies (ecosystem operators) competitive in global markets; successful operation of at least 10 industry (industrial) digital platforms for the main subject areas of the economy (including digital health, digital education and smart city"); successful operation of at least 500 small and medium-sized enterprises in the field of digital technologies and platforms and the provision of digital services" [14].

Thus, the Program plans the results of the construction of platform-type companies and companies-operators of ecosystems, but did not set the task of modernization of industrial companies. 


\section{CONCLUSION}

At the end of the study, we note that in accordance with the processes of digitalization of the industrial sector of the national economy, the directions of further development and transformation of economic security systems that ensure the continuity and protection of information online platforms were proposed. To develop the proposed directions, a systematic analysis of the dynamics of the industrial sector was carried out, the results of the formation of the system of GIS on the basis of the Ministry of industry and trade of Russia were evaluated, and the main target indicators of the road map "TechNet" were considered.

The directions of development and formation of the information platform of the industry of Russia considered in this article opened a number of problems with safety of the online systems connected with its introduction. First of all, the information nature must be addressed in the near future. Today, the issues of increasing information security are brought to the fore due to the frequent cyber-attacks on information systems not only of financial structures, but also of state institutions and industrial production complexes.

The model of competitiveness of the national economy of the Russian Federation on the basis of digital technologies should be based on indicators of digitalization of the industry, especially today, during the deployment of the Fourth industrial revolution.

\section{REFERENCES}

[1] A. V. Babkin, D.D. Burkalev, D.G. Kosten and Yu.N. Vorobyov. The emergence of digital economy in Russia: its essence, features, technical normalization, the problems of development. Scientific technical Bulletin of SPbSPU. Economics. - 2017. - Vol. 10. - No. 3. C. $9-25$.

[2] Strategy of development of information society in the Russian Federation for 2017 - 2030 // Decree of the President of the Russian Federation of may 9, 2017 No. 203 [Electronic resource]. URL: http: // base.garant.ru / 71670570 / (accessed: 14.05.2018)

[3] The effect of the wendigo possessed by Sberbank / the title screen [Electronic resource]. URL: http://expert.ru/expert/2018/23/effektvendigo-ovladel-sberbankom/ (accessed: 14.05.2018)

[4] S.A. Tolkachev, Yu.A. Romanova and D.E. Morkovkin. Analysis of international experience in the development of the digital economy and formation of proposals on its adaptation in the industry of Russia. Scientific works of the Free economic society of Russia. - Vol. 211. No. 3. - P. 229-245.

[5] Improving the competitiveness of domestic industry in the conditions of innovative growth. The collective monograph / under the editorship of J. A. Romanova. - M.: publishing House "Scientific consultant". University of Finance, 2018. - 310 p.

[6] Y.G. Bondarenko. Public administration efficiency increase in investment management. Actual Problems of Economics. 2015. No. 172(10), pp. 89-94.

[7] Kaspersky Lab: cybercriminals are increasingly attacking MAC users-devices. [Electronic resource.] URL: https://www.kaspersky.ru/blog/kaspersky-top3-2017/19713/ (accessed: 20.09.2018)

[8] A. Nasir, M. Shahzad, S. Anwar and S. Rashid. Digital governance: Improving solid waste management through ICT reform in Punjab. ACM International Conference Processing Series. 2017. Part F132087, 3136600 .
[9] Decree of the Government of the Russian Federation of April 18 2016 No. 317 "On the implementation of the National technology initiative" [Electronic resource]. URL: http://www.consultant.ru/document/cons_doc_LAW_196930/92d969 e26a4326c5d02fa79b8f9cf4994ee5633b/ (accessed: 20.09 .2018 )

[10] G.V. Fedotova and B.I. Cerenova. The efficiency of economic systems in the transition to a digital economy [Electronic resource] // Actual problems of management: performance, efficiency, quality : materials of Intern. scientific.- prakt. Conf. (St. Petersburg, 10 November 2017) / redkol.[V. Kuznetsov, et al.]; St. Petersburg state University-St. Petersburg, 2017. - C. 69-71. URL : http://hdl.handle.net/11701/9155.

[11] D. Morkovkin, S. Shmanev, L. Shmaneva. Problems and Trends in Innovative Transformation of Russian Economy and Infrastructure Development // Advances in Economics, Business and Management Research, 3rd International Conference on Economics, Management, Law and Education (EMLE 2017). volume 32. Atlantis Press, 2017. pp. 10-13.

[12] Decree of the President of the Russian Federation of 07.05.2018 N 204 "on national goals and strategic objectives of the Russian Federation for the period up to 2024"[Electronic resource]. URL: http://www.consultant.ru/document/cons_doc_LAW_297432/ (accessed: 26.05.2018)

[13] D.E. Sorokin and S.A. Tolkachev. The Conditions and factors of effective re-industrialization and industrial policy of Russia. Economic revival of Russia. 2015. No. 4. P. 78-99.

[14] Program "Digital economy of the Russian Federation" // Order of the Government of the Russian Federation of July 28, 2017 No. 1632-p [Electronic resource]. URL: goo.gl/H2oKoR (date accessed: 16.05.2018) 